\title{
Matching of the Gray Whales of off Sakhalin and the Pacific Coast of Japan, with a Note on the Stranding at Wadaura, Japan in March, 2016
}

\author{
Gen Nakamura ${ }^{1}$, Hiroshi Katsumata ${ }^{2}$, Yujin Kim¹, Minoru Akagi ${ }^{1}$, Ayumi Hirose ${ }^{1}$, \\ Kazutoshi Arai1,2, Hidehiro Kato ${ }^{1}$ \\ ${ }^{1}$ Laboratory of Cetacean Biology, Tokyo University of Marine Science and Technology, Tokyo, Japan \\ ${ }^{2}$ Kamogawa Sea World, Kamogawa, Japan \\ Email: ${ }^{*}$ nakam1@kaiyodai.ac.jp
}

How to cite this paper: Nakamura, G., Katsumata, H., Kim, Y., Akagi, M., Hirose, A., Arai, K. and Kato, H. (2017) Matching of the Gray Whales of off Sakhalin and the Pacific Coast of Japan, with a Note on the Stranding at Wadaura, Japan in March, 2016. Open Journal of Animal Sciences, 7, 168-178.

https://doi.org/10.4236/ojas.2017.72014

Received: October 14, 2016

Accepted: April 22, 2017

Published: April 28, 2017

Copyright $\odot 2017$ by authors and Scientific Research Publishing Inc. This work is licensed under the Creative Commons Attribution International License (CC BY 4.0).

http://creativecommons.org/licenses/by/4.0/

\begin{abstract}
The coast of Japan is a migratory corridor for the western stock of the gray whales (Eschrichtius robustus), which was once considered as extinct and remains endangered. According to the historical records, from 1955 to 2014, only 21 gray whales occurrence has been recorded in 59 years. However, from 2015 to 2016, intensive occurrence including the seven sightings and the two strandings were noted. In this paper, we found that those sightings were re-sightings of the same individual, which was initially sighted off Sakhalin during August, 2014. On 4 March, 2016, a young female gray whale $(8.9 \mathrm{~m}$ in body length) was stranded at Wadaura beach, Chiba prefecture. We also conducted research on this animal including taking pictures and external measurements. In addition, we flensed this animal to observe the internal organs and collect a skeletal specimen. The reason for the death of this animal remains unclear; however, from its external characteristics, we identified that this animal was not an identical one, sighted off Sakhalin and the coast of Japan from 2014 to 2016. On 5 April, 2016, another young female gray whale (7 $\mathrm{m}$ in body length) was stranded at Arai beach, Shizuoka prefecture. We concluded that from 2015 to 2016, at least three distinct gray whales have migrated along the coast of Japan.
\end{abstract}

\section{Keywords}

Gray Whale, Eschrichtius robustus, Stock, Stranding

\section{Introduction}

The gray whale (Eschrichtius robustus) is the only modern species in this genus 
and the family of Eschrichtiidae. The International Whaling Commission (IWC) manages them as two distinct stocks [1]. Eastern gray whales (California stock) breed near the coastal lagoons of Baja California, Mexico, during winter, whereas they migrate to the Bering and Chukchi seas during summer for feeding [2]. Western gray whales (Asian stock) are believed to breed in the western part of the Hainan Island and migrate to the coast of Sakhalin in the Okhotsk Sea for feeding [3]. These two stocks show distinct population dynamics. Eastern gray whales were depleted by historical American whaling as well as modern whaling, however, it was dramatically recovered after 1960s, with individuals estimated at approximately 20,990 (95\% Highest Posterior Density Interval (HDPI) 12,230 22,900), almost reaching the limit of the carrying capacity of their habitat [4]. On the other hand, land-based whaling at Ulsan or other modern whaling also depleted the abundance of the western gray whales. During 1960, it was believed that the western gray whales were near extinct [5]. Subsequently, although the western gray whales were no longer in immediate danger of extinction [6], the abundance of this population has not yet recovered [7] [8]. The population of the western gray whales is estimated to be only 121 (95\% CV 112 - 130) individuals by IWC scientific committee; therefore, concerns of extinction [9].

Japan locates from the Okhotsk Sea in the north, which is the feeding ground of the western gray whales, to the East China Sea in the south. Therefore, the coast of Japan is thought to be the migratory corridor for the western gray whales [10]. Gray whales scarcely appeared around the Japanese coast. From 1955 to 2014, only 21 sightings or strandings of gray whales have been reported along the Japanese coast [11]. From 2015 to April 2016, seven sightings and two strandings of gray whales have been reported. The sightings at Kozushima Island, Niijima Island, and Miho in 2015 were identified as identical animal, which was also sighted off Sakhalin Island in 2014 [11] [12]. However, no information is available on whether other sighted and stranded animals are of the same individual. In addition, we had an opportunity to conduct a detailed observation of one of the stranded animals at Wadaura beach, Minamiboso city, Chiba prefecture on 4 March, 2016.

Therefore, in the current report, we aimed to integrate and identify individuals within recent sightings as well as report the detail of the stranded animal at Wadaura beach.

\section{Materials and Methods}

The sighting and stranding data before April 2015 were cited from published papers [11] [12]. The data after May 2015, including pictures, sighting locations, and dates were sourced directly from the individual people who found the gray whales and submitted information to the Fisheries Agency of Japan and TUMSAT or posted to the internet through the Social Networking Service (SNS) and/or news. We also collected the data from the animal (female, $8.90 \mathrm{~m}$ ) stranded at Wadaura beach, Chiba prefecture on 4 March, 2016. 


\section{Results}

\subsection{Sightings and Stranding of Gray Whales from March 2015 to April 2016}

During this period, local divers or citizens had coincidentally sighted gray whales (Figure 1, Table 1). In 2015, four sightings had been reported at Kozushima Island, Tokyo (20 March); Niijima Island, Tokyo (24 March); Teradomari, Niigata prefecture (31 March); and Miho beach, Shizuoka (19 April) [11]. As mentioned above, sightings made at Kozushima and Niijima Islands, and Miho beach have been identified as the same animal, which was also sighted off Sakhalin Island [12].
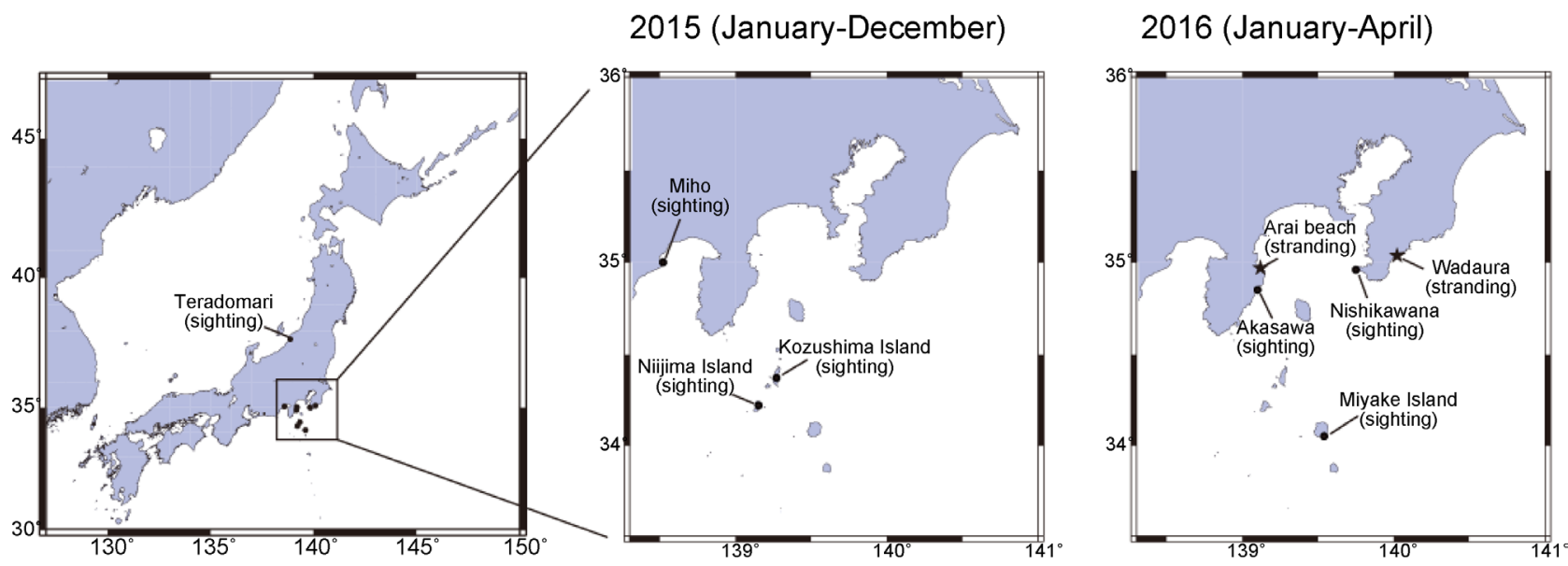

Figure 1. Location of the sighting ( ) and stranding ( $\star$ ) from January, 2015 to April, 2016.

Table 1. Sighting and stranding of the gray whales from March 2015 to April 2016.

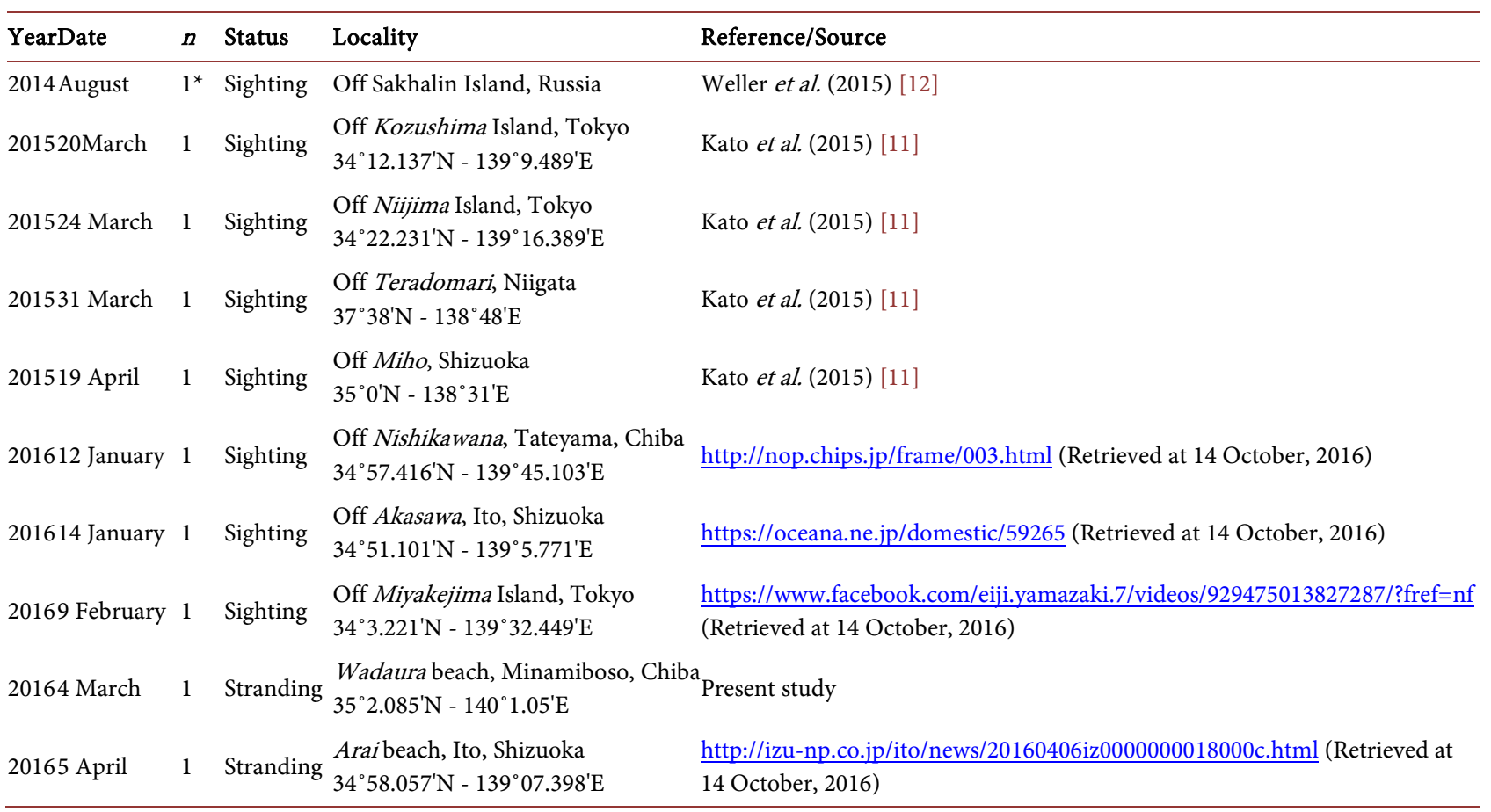

*This animal was first sighted with her mother. 
From January to April, 2016, three sightings and two strandings of gray whales have been reported. Locations and other information are as follows;

1) Off Nishikawana (sighting): A gray whale was sighted by a local diver off Nishikawana, Tateyama City, Chiba prefecture $\left(34^{\circ} 57.416^{\prime} \mathrm{N}-139^{\circ} 45.103^{\prime} \mathrm{E}\right)$ on 12 January, 2016. Tateyama is in the southern tip of Boso peninsula. The diver captured video footage of the right surface of the whale's body.

2) Off Akasawa (sighting): A gray whale was sighted by a local diver off $A$ kasawa, Ito City, Shizuoka prefecture $\left(34^{\circ} 51.101^{\prime} \mathrm{N}-139^{\circ} 5.771^{\prime} \mathrm{E}\right)$ on 14 January, 2016. Akasawa is in the middle part of Izu peninsula and faces Sagami bay. The diver captured images and videos of the left side of the animal's body.

3) Off Miyakejima Island (sighting): A gray whale was sighted at the pier of Miike port, Miyakejima Island (34 $\left.3.221^{\prime} \mathrm{N}-139^{\circ} 32.449^{\prime} \mathrm{E}\right)$ on 9 February, 2016. Miyakejima Island is one of the seven islands comprising Izu Archipelago and is approximately $180 \mathrm{~km}$ south of Tokyo. Several tourists and local people observed this animal. Images and videos of the dorsal surface were obtained.

4) Wadaura beach (stranding): A young female gray whale was stranded at Wadaura beach, Minamiboso City, Chiba prefecture $\left(35^{\circ} 2.085^{\prime} \mathrm{N}-140^{\circ} 1.05^{\prime} \mathrm{E}\right)$ on 4 March, 2016. External measurement, sampling, and other research were conducted by researchers from the Tokyo University of Marine Science and Technology (TUMSAT) and the Kamogawa Sea World, the details of which are described in another chapter of this paper.

5) Arai beach (stranding): A young female gray whale was stranded at Arai beach, Ito, Shizuoka prefecture $\left(34^{\circ} 58.06^{\prime} \mathrm{N}-139^{\circ} 07.40^{\prime} \mathrm{E}\right)$ on 5 April, 2016. Two days before, this animal was found dead and floating near the coast of Atami city, approximately $15 \mathrm{~km}$ north of Arai beach. Researchers from the National Museum of Nature and Science, Tokyo conducted the research. According to the news released, this animal was a young female with a body length of $7 \mathrm{~m}$.

\subsection{Photo-Identification of Sighted and Stranded Animals.}

The present study compared the external characteristics of each animals sighted and stranded during 2016 to identify individuals.

1) Nishikawana animal: The photograph of this animal was captured from the right side. Therefore, we compared the positions of the white spots on the flipper. These spots on the Nishikawana animal clearly coincided with those on the animal which was sighted at off Kozushima Island, during 2015 (Figure 2).

2) Akasawa animal: The photograph of this animal was captured from the right side. The photographs were of insufficient clarity to identify the individual definitively. However, from the white spots pattern of the body, this animal appears to be the same individual which was sighted at off Nishikawana.

3) Miyakejima animal: Dorsal surface of this animal was photographed from the pier of Miike port of Miyakejima Island. Compared to the dorsal view of the Kozushima animal, the positions of the barnacles are distinctly different. However, the white spots of the dorsal surface and around the nasal area coincided with those on the Kozushima animal (Figure 3). Therefore, we concluded that this animal is also the Kozushima animal. 
Nishikawana (12 January, 2016) Kozushima Island (20 March, 2015)
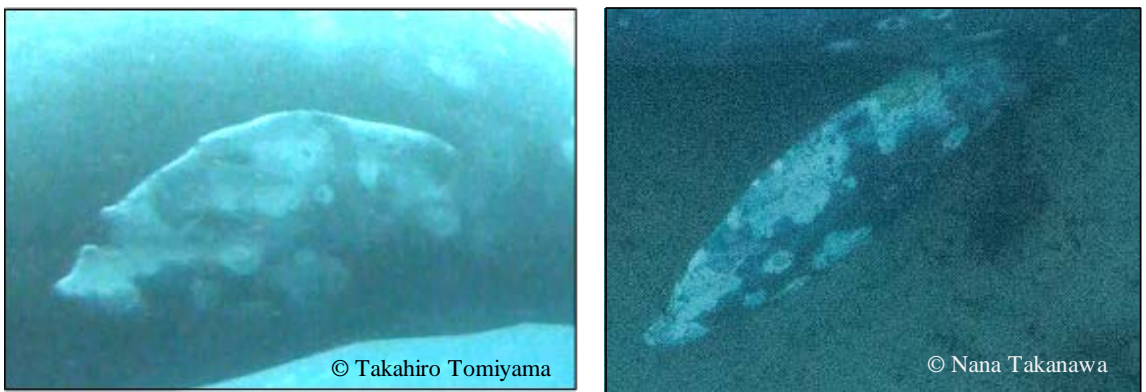

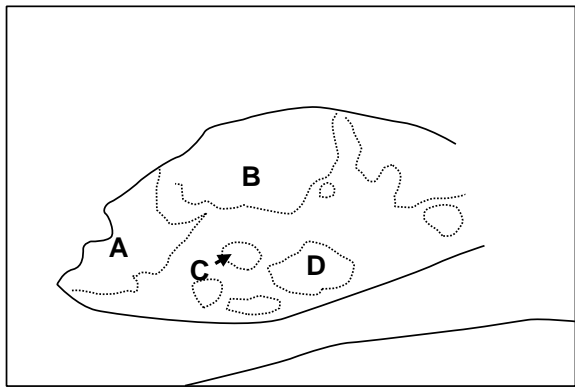

(a)

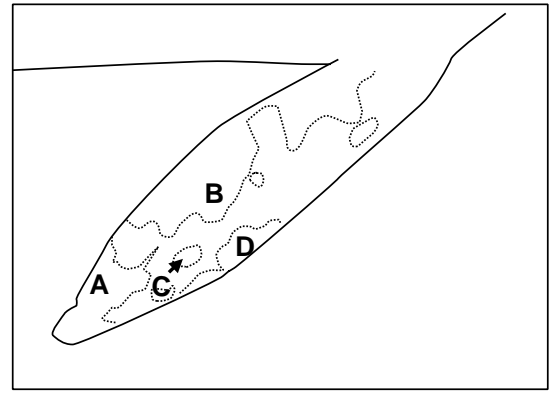

(b)

Figure 2. Comparison of the white spots of the right flipper between Nishikawana (a) and Kozushima animal (b). The shape and distribuiton of the white spots were matched. A; White spots at the tip of fliper. B; Largest white spots at dorsal ridge. C; White spots surrounded by $\mathrm{A}, \mathrm{B}$ and $\mathrm{D}$. D; White spots at the center of the flipper.

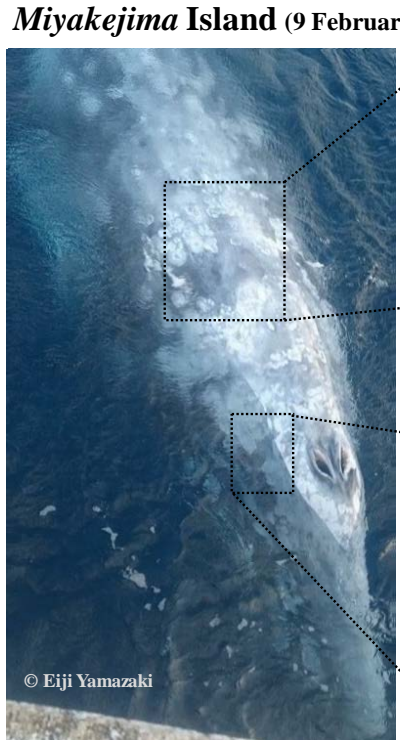

(a)

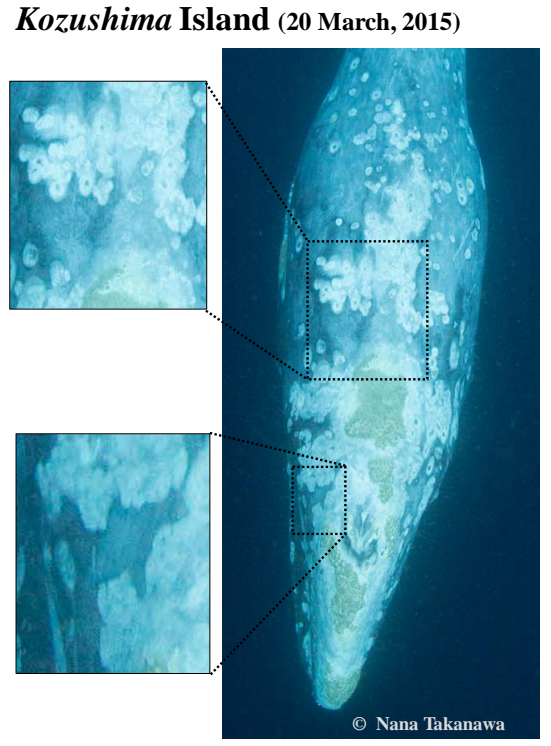

(b)

Figure 3. Comparison of the white spots of the dorsal surface between Miyakejima (a) and Kozushima animal (b). The shape and distribuiton of the white spots were matched.

4) Wadaura animal: This animal was found floating on its back and was pulled up with left side up. Therefore, we could not obtain sufficient images of the right surface. For the photo identification, we used the shape of the flipper. The $\mathrm{Ni}$ shikawana animal (confirmed as identical to the Kozushima animal) had a notch 
on the right flipper. On the other hand, in the Wadaura animal, such a notch was not observed (Figure 4). Therefore, we concluded that this animal must be a distinctly different individual from those previously reported.

5) Arai animal: When this animal was found, it had already been dead for a few days. The body was in an advanced stage of decomposition, and its skin had almost totally been removed. Therefore, we could not identify the individual from the photograph.

\subsection{Status of the Stranded Animal at Wadaura Beach}

On 4 March, 2016, a single dead gray whale was found floating outside the Wadaura beach, Minami-Boso City, Chiba prefecture (Figure 5, Table 2). When this animal was found, its intestines were protruding from its mouth and the smell of decomposition was evident. On the following day (5 March), the research staff of the TUMSAT and Kamogawa Sea World arrived at the site and conducted research. However, the site where the animal was floating was a shallow $(0.5-1.0 \mathrm{~m})$ rocky area and was not suitable for research. Therefore, the animal was towed by a boat to a sandy beach approximately three $\mathrm{km}$ south from the Wada port, where it was hoisted onto the beach using a power shovel. We collected images of the external body surface and skin samples for DNA analysis and ectoparasites, such as whale barnacles and whale rice. In addition, we measured body length, 21 external measurement points, and eight points of blubber thickness (Appendix). After the external observation, the animal was flensed for the internal observation and sampling of the bone structure.

This animal was a young female of $8.90 \mathrm{~m}$ in body length. The age of this animal was unclear because it's ear plug was not yet fully developed or corrupted. Using the growth curve relating age and body length proposed by Sumich (1986) [13], this animal was estimated to be approximately $18-19$ months of age. The blubber thickness was sufficient $(4.0-17.6 \mathrm{~cm})$, and the large intestine (protruding from its mouth) was filled with feces. We could not study other internal organs, such as the lungs, heart, stomach and ovaries, as they were decomposed and some had been lost outside the body. From the external observation, no

Wadaura beach (5 March, 2016)

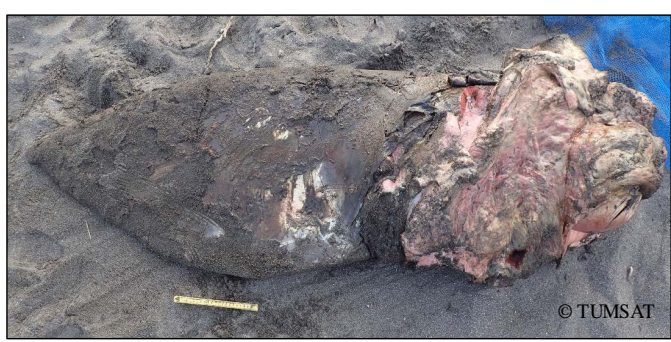

(a)
Nishikawana (12 January, 2016)

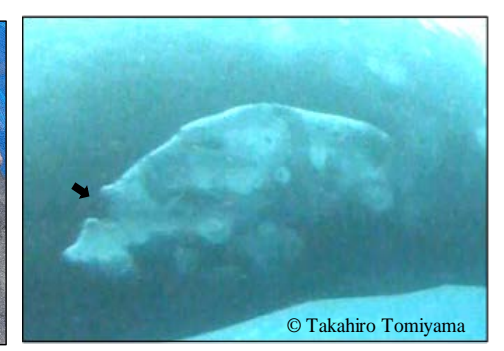

(b)

Figure 4. Comparison of the shape of the right flipper between Wadaura (a) and Nishikawana animal (b). Note that the picure of the flipper of Wadaura animal is showing inner surface. Nishikawana animal had a notch (pointed by the arrow) at dorsal ridge of flipper, whereas such notch was not observed in Wadaura animal. 


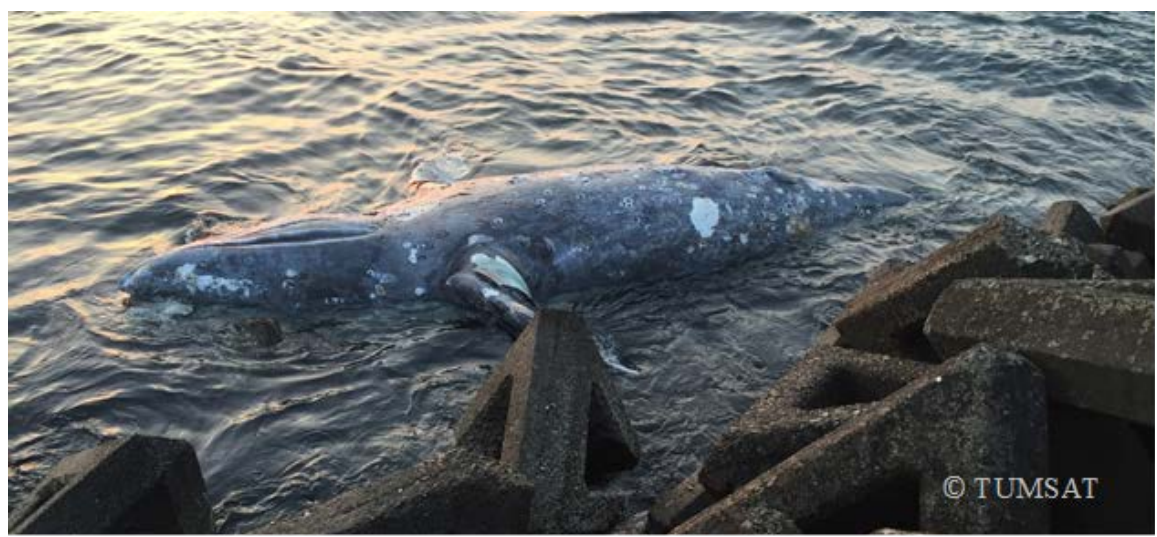

(a)

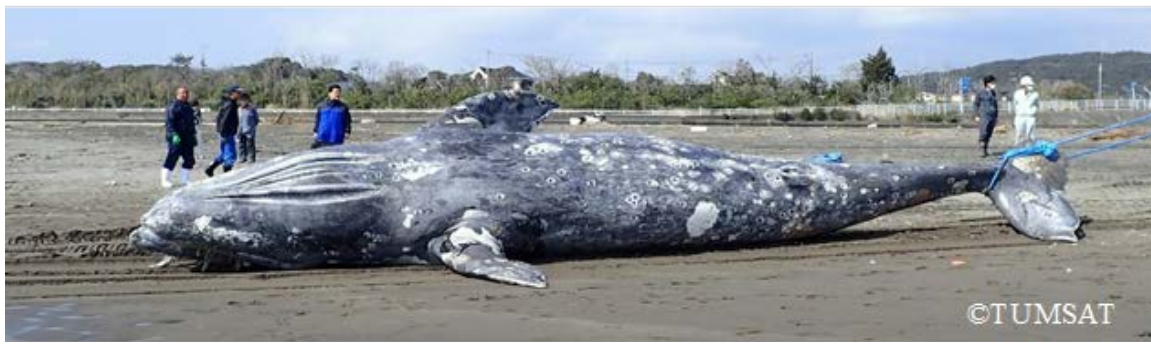

(b)

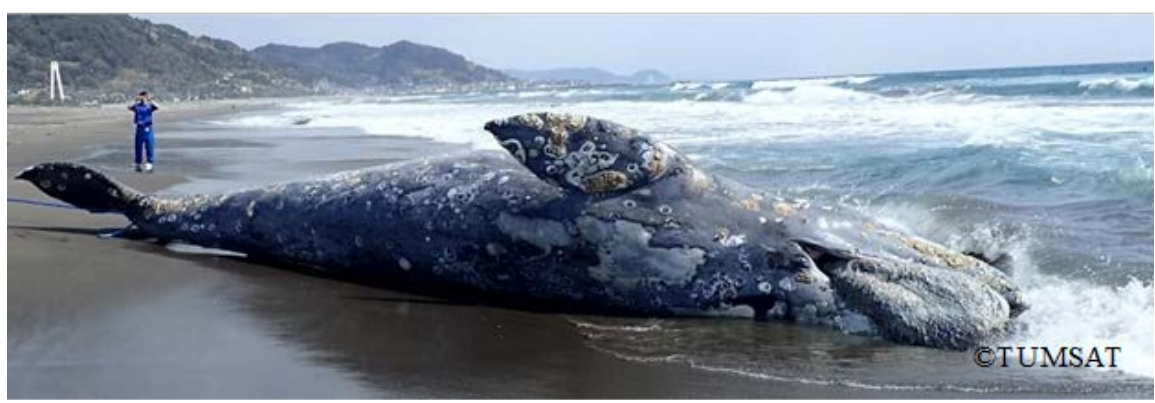

(c)

Figure 5. The dead gray whales found floating at Wadaura beach, Chiba prefecture (a). Ventral surface (b) and left lateral view (c) of the animal, landed at the beach for observation.

human-induced injuries such as those from ship strikes or entanglement were observed. In addition, there were no traces of killer whale attacks. Therefore, we could not determine the cause of death of this animal.

\section{Discussion}

According to previous studies, this animal was firstly observed as a calf off Sakhalin during August 2014 [11] [12]. This indicates that this animal migrates to the coast of Japan and uses as migratory corridor for two consecutive years.

We could not define weather the animal stranded at Arai beach was the identical to the Kozushima animal or not only from its picture. Gray whale birth at $4.5 \mathrm{~m}$ in body length and reaches $7.0 \mathrm{~m}$ in six month after birth. After weaning, increase rate diminish and reach $8 \mathrm{~m}$ by one year and $9 \mathrm{~m}$ by two years [13]. The body length of the Arai animal was reported as $7 \mathrm{~m}$. Therefore, this animal was 
Table 2. Evidence of matching of the gray whale sighted off Sakhalin and the coast of Japan.

\section{Locality}

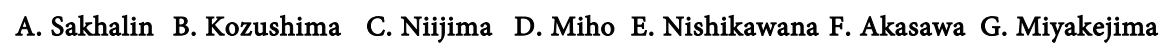

A. Off Sakhalin Island, Russia August, 2014

B. Off Kozushima Island, Tokyo 20 March, 2015

C. Niijima Island, Tokyo 24 March, 2015

D. Off Miho, Shizuoka 19 April, 2015

E. Off Nishikawana, Tateyama, Chiba 12 January, 2016

F. Off Akasawa, Ito, Shizuoka 14 January, 2016

G. Off Miyakejima Island, Tokyo 9 February, 2016

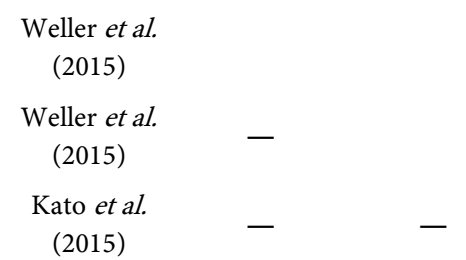

\section{White spots of} the right flipper were matched. (Figure 4)

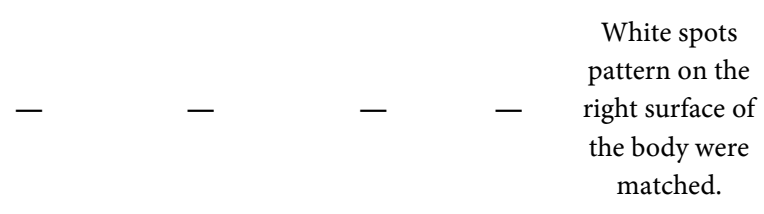

estimated about 6-month-old. On the other hand, from the sighting record, $\mathrm{Ko}$ zushima animal was estimated to 20-month old [12], when Arai animal was stranded (April, 2016) and should be about $9 \mathrm{~m}$ in body length. Therefore, we concluded that Arai animal was not identical to the Kozushima animal.

From the historical record, 21 occurrences of gray whales have been noted from 1955 to 2014 [11]. Sighting rate was only 0.36 animals/year on average and the sighting of the gray whales around the coast of Japan is very rare. However, from 2015 to 2016, nine occurrences were noted. Present study revealed that within these sightings, some of them were re-sightings of the same animal. However, we also indicated that at least three distinct animals have been migrated to the Japanese coast in this period. The increase in the numbers of occurrence in these two years may indicate the recovery of the western gray whales. On the other hand, certain studies have suggested the possibility of the expansion of the eastern gray whales to the western gray whales feeding ground and mixing of these two stocks [14]. At present, the information is not enough to conclude whether the increase of the sightings is the result of the recovery of the western gray whales.

\section{Conclusion}

During 2015 through 2016, a total of seven sightings and two strandings of gray whales were recorded around the coast of Japan. Within these sightings, we concluded that at least three distinct animals were observed, one of which has been 
recorded at Sakhalin during 2014 and at Kozushima during 2015. We found that this animal migrated to the coast of Japan for two consecutive years.

\section{Acknowledgements}

We are grateful to the nature photographer Nana Takanawa, Takahiro Tomiyama of the Nishikawana Ocean Park, Tsuyoshi Matsuzaki of the diving service "Mieux", and Eiji Yamazaki and Kohei Miwa who sighted the gray whales and provided us with valuable data. We also express gratitude to the following people who assisted our research of the animal stranded at Wadaura. Toshihide Iwasaki and Tomio Miyashita of the National Research Institute of the Far Seas Fisheries are thanked for providing information of the stranding of the gray whale. Masako Iwasaki and Mika Shoji are thanked for providing contact to the local governor and officials. Kazunori Kurokawa of the Higashi-Awa fisheries cooperatives, the crew of the Ama-diver association, and Kentaro Wada, the captain of Shoji Masakichi Shoten Co. Ltd., are thanked for towing the dead whale to the beach. Ryuta Abe and Tetsuya Masaki of Gaibo Hogei Co. Ltd., and Etsuko Katsumata and crew of Kamogawa Sea World are thanked for flensing the whales, thereby contributing to rapid and accurate research. We sincerely thank Naohito Okazoe and Haruya Kumakiri of the Fisheries Ministry of Japan and Keiji Ono of Minami Boso city for the administrative support of this research. Also we would like to thank Enago (www.enago.jp) for the English language review.

\section{References}

[1] Swartz, S.L., Taylor, B.L. and Rugh, D.J. (2006) Gray Whale Eschrichtius robustus Population and Stock Identity. Mammal Review, 36, 66-84. https://doi.org/10.1111/j.1365-2907.2006.00082.x

[2] Moore, S.E. and Ljungblad, D.K. (1984) Gray Whales in the Beaufort, Chukchi and Bering Seas: Distribution and Sound Production. In: Jones, M.L., Swartz, S. and Leatherwood, S., Eds., The Gray Whale, Eschrichtius robustus, Academic Press Inc., New York, 543-559.

[3] Nerini, M. (1984) A Review of Gray Whale Feeding Ecology. In: Jones, M.L., Swartz, S. and Leatherwood, S., Eds., The Gray Whale, Eschrichtius Robustus, Academic Press Inc., New York, 423-450.

[4] Durban, J., Weller, D., Lang, A. and Perryman, W. (2013) Estimating Gray Whale Abundance from Shore-Based Counts Using a Multilevel Bayesian Model. Paper SC/65a/BRG02, 65a IWC Scientific Committee, 9 p.

[5] Bowen, S.L. (1974) Probable Extinction of the Korean Stock of the Gray Whale (Eschrichtius robustus). Journal of Mammalogy, 55, 208-209. https://doi.org/10.2307/1379272

[6] Kato, H. and Kasuya, T. (2002) Some Analyses on the Modern Whaling Catch History of the Western north Pacific Stock of Gray Whales (Eschrichtius robustus), with Special Reference to the Ulsan Whaling Ground. Journal of Cetacean Research and Management, 4, 277-282.

[7] Brownell, R.L. and Chun, C. (1977) Probable Existence of the Korean Stock of Gray Whales (Eschrichtius robustus). Journal of Mammalogy, 58, 237-239.

https://doi.org/10.2307/1379584 
[8] Weller, D.W., Burdin, A.M., Wursig, B., Taylor, B.L. and Brownell, R.L. (2002) The Western Gray Whale: A Review of Past Exploitation, Current Status and Potential Threats. Journal of Cetacean Research and Management, 4, 7-12.

[9] Cooke, J.G., Weller, D.W., Bradford, A.L., Burdin, A.M. and Brownell, R.L. (2007) Population Assessment of Western Gray Whales in 2007. Paper SC/59/BRG41, 59th IWC Scientific Committee, $10 \mathrm{p}$.

[10] Weller, D.W., Bradford, A.L., Kato, H., Bando T., Ohtani S., Burdin A.M. and Brownell. R.L. (2008) Photographic Match of a Western Gray Whale between Sakhalin Island, Russia and Honshu, Japan: First Link between Feeding Ground and Migratory Corridor. Journal of Cetacean Research and Management, 10, 89-91.

[11] Kato, H., Kishiro, T., Bando, T., Ohizumi, H., Nakamura, G., Okazoe, N., Yoshida, H., Mogoe, T. and Miyashita, T. (2015) Status Report of Conservation and Researches on the Western North Pacific gray Whales in Japan, May 2014-April 2015. Paper SC/66a/BRG/18, 66a IWC Scientific Committee, 10 p.

[12] Weller, D.W., Takanawa, N., Ohizumi, H., Funahashi, N., Sychenko, O.A., Burdin, A.M., Lang, A.R. and Brownell, R.L. (2015) Photographic Match of a Western Gray Whale between Sakhalin Island, Russia and the Pacific Coast of Japan. Paper SC/66a/BRG/17, 66a IWC Scientific Committee, 2 p.

[13] Sumich, J.L. (1986) Growth in Young Gray Whales (Eschrichtius robustus). Marine Mammal Science, 2, 145-152. https://doi.org/10.1111/j.1748-7692.1986.tb00035.x

[14] Mate, B.R., Ilyashenko, V.Y., Bradford, A.L., Vertyankin, V.V., Tsidulko, G.A., Rozhnov, V.V. and Irvine, L.M. (2015) Critically Endangered Western Gray Whales Migrate to the Eastern North Pacific. Biological Letters, 11, Article ID: 20150071. https://doi.org/10.1080/028418501127346846 


\section{Appendix}

Body proportion of the gray whale stranded at Wadaura, Japan.

[Body proportion, girth and blubber thickness]

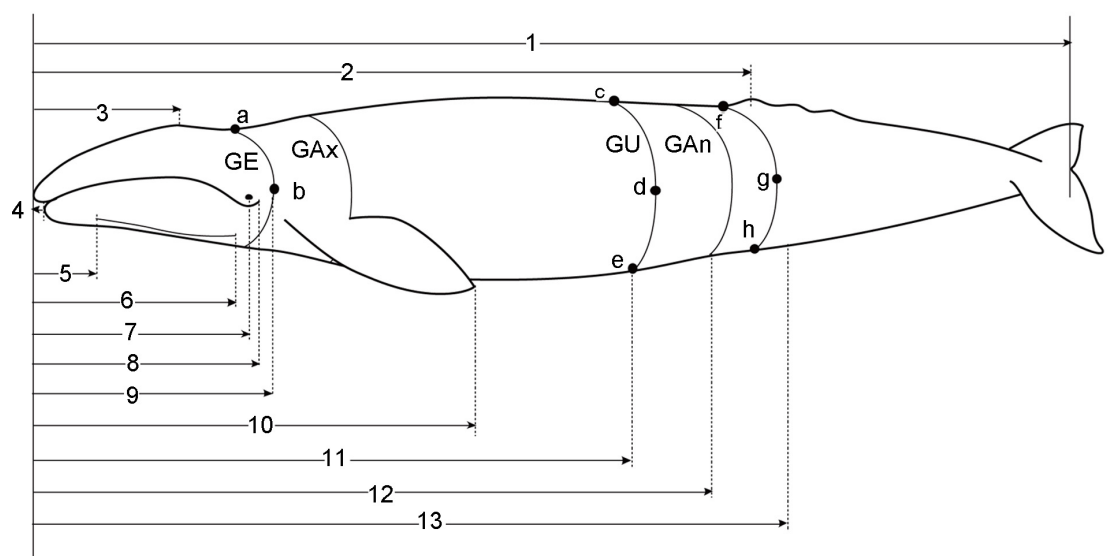

[Flipper]

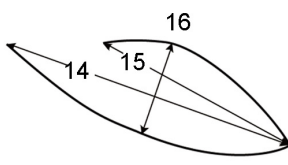

[Tail fluke]

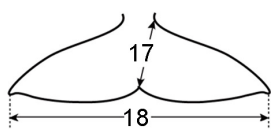

\# Measurement point

1 Total length

2 Tip of snout to the highest point of dorsal fin

3 Tip of snout to blowhole

4 Projection of tip of snout to lower jaw

5 Tip of snout to the beginning of ventral groove

6 Tip of snout to the terminal point of ventral groove

7 Tip of snout to eye (center)

8 Tip of snout to angle of gape

9 Tip of snout to ear

10 Tip of snout to tip of flipper

11 Tip of snout to umbilicus

12 Tip of snout to reproductive aperture

13 Tip of snout to anus

14Flipper, tip to anterior insertion

15 Flipper, tip to posterior insertion

16Flipper, maximum width

17Flukes, depth

18 Flukes, tip to tip

\begin{tabular}{|c|c|c|c|}
\hline $\mathrm{cm}$ & $\#$ & Measurement point & $\mathrm{cm}$ \\
\hline 890 & GE & Girth at ear & 193 \\
\hline 580 & GAx & Girth at axilla & 231 \\
\hline 134 & GU & Girth at umbilicus & 203 \\
\hline 10 & GAn & Girth at anus & 135 \\
\hline $\begin{array}{l}44 \\
196\end{array}$ & $\mathrm{a}$ & Blubber thickness at GE (dorsal site) & 6.8 \\
\hline $\begin{array}{l}152 \\
145\end{array}$ & $\mathrm{~b}$ & Blubber thickness at GE (lateral site) & 4.0 \\
\hline $\begin{array}{l}198 \\
394\end{array}$ & c & Blubber thickness at GU (dorsal site) & 14.6 \\
\hline $\begin{array}{l}471 \\
584\end{array}$ & $\mathrm{~d}$ & Blubber thickness at GU (lateral site) & 8.8 \\
\hline $\begin{array}{l}629 \\
143\end{array}$ & e & Blubber thickness at GU (ventral site) & 10.0 \\
\hline $\begin{array}{l}117 \\
58\end{array}$ & $\mathrm{f}$ & Blubber thickness at the front of the ridge (dorsal site) & 17.6 \\
\hline 77 & & & \\
\hline 216 & $\mathrm{~g}$ & Blubber thickness at the front of the ridge (lateral site) & 6.1 \\
\hline & $\mathrm{h}$ & Blubber thickness at the front of the ridge (ventral site) & 10.8 \\
\hline
\end{tabular}


Submit or recommend next manuscript to SCIRP and we will provide best service for you:

Accepting pre-submission inquiries through Email, Facebook, LinkedIn, Twitter, etc. A wide selection of journals (inclusive of 9 subjects, more than 200 journals)

Providing 24-hour high-quality service

User-friendly online submission system

Fair and swift peer-review system

Efficient typesetting and proofreading procedure

Display of the result of downloads and visits, as well as the number of cited articles Maximum dissemination of your research work

Submit your manuscript at: http://papersubmission.scirp.org/

Or contact ojas@scirp.org 